\title{
Hot Pepper Fusarium Wilt (Fusarium oxysporum f. sp. capsici): Epidemics, Characteristic Features and Management Options
}

\author{
Endriyas Gabrekiristos ${ }^{1} \&$ Tola Demiyo ${ }^{1}$ \\ ${ }^{1}$ Melkassa Agricultural Research Center, Ethiopian Institute of Agricultural Research, Adama, Ethiopia \\ Correspondence: Endriyas Gabrekiristos, Melkassa Agricultural Research Center, Ethiopian Institute of \\ Agricultural Research, P.O. Box 436, Adama, Ethiopia. E-mail: endriasgabre@gmail.com
}

Received: June 13, 2020

Accepted: August 28, $2020 \quad$ Online Published: September 15, 2020

doi:10.5539/jas.v12n10p347

URL: https://doi.org/10.5539/jas.v12n10p347

\begin{abstract}
Hot pepper (Capsicum annum L.) is one of the important cash crops to Ethiopian smallholder farmers and an important agricultural commodity which contribute to export earnings. In Ethiopia, this high value crop is constrained by powdery mildew, Phytophthora leaf blight, Fusarium wilt, bacterial leaf spot, bacterial wilt, bacterial soft rot and pepper motile virus. Among this diseases, wilt disease caused by Fusarium oxysporum f.sp. capsici (FOC) is one of the major pathogen that constrained production and productivity of hot pepper in Ethiopia mainly the Central Rift valley. In Ethiopia, hot pepper fusarium wilt is reported in all production regions in different magnitude. The highest wilt incidence due to fusarium is $90 \%$ in some Farmers association of Alaba districts in South Nation Nationalities and peoples of Ethiopia. The economic yield losses due to Fusarium wilt has been estimated at 68 to $71 \%$. Infection and disease development in Fusarium wilt is favored by warm soil temperature, low soil moisture, susceptible host, virulent pathogen and 5.0 to $6.0 \mathrm{pH}$ levels; are some of epidemic factors. Fusarium is reproduced by sexually by teleomorphs and asexually by microconidia, macroconidia and chlamydospore. From the Central rift valley of Ethiopia, 49 FOC isolates were identified based on micro and macroscopic characteristics and the isolate having pink colony color, 3-5 septa forming conidia on potato dextrose agar, perform the most pathogenic ability to Mareko Fana Variety. This pathogen has an over wintering stage called chlamydospore which can exist in the soil for more than ten years without the host. Hot pepper fusarium wilt can be managed by host resistance, biological agent, botanicals and fungicide. In Ethiopia, pepper screening for resistant source, in vitro evaluation of bioagents and fungicides were done. In this review attempt has been made to summarize relevant scientific studies on this economically important crop, hot pepper fusarium wilt and associated factors in Ethiopia as well as its different disease management options, challenges and future prospects.
\end{abstract}

Keywords: epidemics, Fusarium wilt, hot pepper, management options

\section{Introduction}

Hot pepper (Capsicum annum L.) is native to Latin America and belongs to the family Solanceae (Rodriguez et al., 2008). The exact time of pepper introduction to Africa in general and Ethiopia in particular is not known. Probably Portuguese had introduced hot pepper to Ethiopia in early $17^{\text {th }}$ century (Huffnagel, 1961). Nowadays, pepper is produced as vegetable and spice nearly in most parts of Ethiopia and the southern Rift valley regions are the major production areas (Tameru, 2004; Berke, 2002). In Ethiopian, hot pepper is one of the cash crops to smallholder farmers and contributes to export earnings (Beyene \& David, 2007). The nutritional value of hot pepper merits special attention. It is rich source of vitamin $\mathrm{A}, \mathrm{E}$ and contains five to six times as much vitamin $\mathrm{C}$ as an orange or a lemon; this makes an ideal vegetable to prevent flu colds more than any other vegetable crop (Boselad \& Votava, 2000). The average daily consumption of hot pepper by an Ethiopian adult is estimated to be $15 \mathrm{~g}$ which is higher than tomatoes and most other vegetables (MARC, 2004), indicating the significance of the crop in the country.

According to FAOSTAT (2017), a world average production of $32.3 \mathrm{t} / \mathrm{ha}$ green and $3.8 \mathrm{t} / \mathrm{ha}$ dry pepper have been reported. In Ethiopia, average dry and green hot pepper production is $1.6 \mathrm{t} / \mathrm{ha}$ and $10.7 \mathrm{t} / \mathrm{ha}$, respectively (Abraham et al., 2016), which is far below the world's average. In 2018, the total area used for cultivation of green and red pepper in Ethiopia was 152, 7523 ha with an estimated total production of 2,647, 22.5 t. Interestingly, this data shows that hot pepper covers $73.1 \%$ of all the area under vegetables in Ethiopia (CSA, 2018). 
Despite the importance of hot pepper in Ethiopia, total crop failure due to diseases has been common and sometimes farmers are forced to abandon their production due to excessive disease pressure in the field (Tameru et al., 2003). Among hot pepper diseases, Powdery mildew, Leaf blight, Wilt and Pepper mottle virus (BARC, 2000; Kassahun et al., 2016; Korobko et al., 1986) have been reported in Ethiopia. Recently, wilt causing pathogens are becoming the leading problems reported by causing $86.4 \%$ wilt incidence due to fusarium wilt in Ethiopia (Assefa et al., 2015). The stated diseases vary based on environmental, varietal and pathogen factors. Regarding fusarium wilt, its significance depends on host reaction, virulence level of the pathogen, soil type and soil micro-climate (Goldberg, 2010). For instance, high temperature and moisture play a great role for FOC epidemics (Sanogo, 2003). In Ethiopia, clay loam soil type was found to be favorable for fusarium wilt disease development (Assefa et al., 2015).

In plant disease management, there is a world-wide need to adopt the practice of sustainable agricultural strategies which is environment-friendly, less dependent on agricultural chemicals and less damaging to soil and water resources. Regarding fusarium wilt, effective means of control in general include the use of soil disinfestations and resistant/tolerant plant materials. In particular, the management options so far recommended for the control of fusarium wilt of pepper in Ethiopia include the use of crop rotation, fallowing, resistant varieties, and in the severe cases application of chemicals (EARO, 2004). Nevertheless, these management options should be evaluated to be applicable and bring tangible changes to the end users. The use of resistant varieties is the best strategy for disease control and one of the most effective alternative approaches to control wilt diseases (Sheu et al., 2006). This paper discusses the Fusarium wilt disease and the pathogen, Epidemics, management options and prospects to improve research methods in systemic pathogens.

\section{Fusarium Wilt of Hot Pepper and Associated Factors in Ethiopia}

Hot pepper production and productivity is in decreasing trend even though it is a highly profitable commercial spice and vegetable crop. Currently production of pepper is under severe threat by several biotic and abiotic factors. Improper agronomic practices and inappropriate use of fertilizers lead to the low yield of chilli (Jack et al., 2006). These problems are causing major issues with the supply of pepper and threaten the sustainability of farmer livelihood as reported by (Thijs, 2010).

Table 1. Important diseases of hot pepper in Ethiopia, 2018

\begin{tabular}{lll}
\hline Disease & Causal pathogen & Reference \\
\hline Powdery mildew & Leveillula taurica & Mengistu (1994) \\
Anthracnose & Colletotrichum gloeosporioides & Fekadu and Dandena (2006) \\
Fusarium wilt & Fusarium oxysporum & BARC (2000) \\
Root rot & Rhizoctonia solani, Fusarium spp. & BARC (2000) \\
Verticillium wilt & Verticillium spp. & BARC (2000) \\
Phytophthora blight & Phytophthora capsici & BARC (2000) \\
Bacterial leaf spot & Xanthomonas campestris & Fekadu and Dandena (2006) \\
Bacterial wilt & Ralstonia solanacearum & Fikre (2006) \\
Virus & Pepper mottle virus & Bos (1974) \\
\hline
\end{tabular}

Note. BARC: Bako Agricultural Research Center.

In Ethiopia among hot pepper diseases, fungi caused by Fusarium spp., Phytophthora spp., Rhizoctonia solani and Cercospora capsici (Shiferaw \& Alemayehu, 2014); bacterial diseases caused by Ralstonia solanacearum (Kassahun et al., 2016) and viral disease caused by pepper mottle virus have been reported as major ones (Korobko et al., 1986). The most recent report by Gabrekiristos (2020) indicates that, in the Central Rift valley of Ethiopia, Farmers respond, the production of hot pepper is threaten by 'Adriq' means dry and 'Ametmet' means softening for about twenty years. The terms are Amharic and associated with the symptom caused by Fungi and bacteria respectively.

\section{Fusarium oxysporum f. sp. capsici}

Causal agent: Fusarium wilt disease, caused by the soil-borne fungus, F. oxysporum f. sp. capsici is the most important disease on hot pepper that reduces growth, fruit yield and quality (Sahi \& Khalid, 2007; Wongpia \& Lomthaisong, 2010). The pathogen causes vascular wilt on large variety of economically important crops 
worldwide (Ortoneda et al., 2004). This fungus is a necrotrophic, soil-borne with worldwide distribution in tropical to sub-tropical areas (Booth, 1971).

F. oxysporum f. sp. capsici was found to be specific to vascular wilt of bell pepper (Black \& Rivelli, 1990). The teleomorphs/sexual type of Fusarium species are mostly classified in the genus Gibberella and for a smaller number of species; Hemanectria and Albonectria genera are the teleomorphs (Moretti, 2009). While all strains are capable of saprophytic growth, some are pathogenic to different plant species, resulting in wilts, crown, and root rots (Burgess, 1981). Pathogenic strains typically are extremely host specific and are classified into $>150$ formae speciales based on the plant host(s).

\subsection{Morphological Characteristics}

Morphological characteristics are by far and away the most commonly used criteria for identifying Fusarium species. Macro-conidia are the single most important cultural character in the identification of Fusarium species. In many cases the morphology of this spore alone is sufficient to identify a culture to species. Kelaniyangoda et al. (2011) reported that white to pink color colony of the culture and macroconidia were hyaline and sickle shaped on potato dextrose agar (PDA). The colony color of Fusarium varies from white to pink and the hyphae are septated and branched (Kaushal, 2016). Similarly, Endriyas et al. (2019) reported that, out of 49 FOC isolates, 35 (71.4\%) had Pink colony color and the remaining 14 isolates $(28.6 \%)$ had white colony color on PDA. Ferniah et al. (2014) reported that, morphological characters of $F$. oxysporum with white cottony aerial mycelium and purple on the reverse side with $4-5 \mathrm{~cm}$ diameter at 5 days incubation on potato dextrose agar. The hyphae of fusarium are septated, branched and produce microconidia, macroconidia and chlamydospores (Endriyas et al., 2019). The micro- and macro-conidia are formed externally on hypha-like conidiophore, which categorizes Fusarium as a Hyphomycete. Chlamydospores are formed single or in pairs from normal hypha which undergoes increased growth and thickening of their cell wall (Nelson et al., 1994). Conidia were grown from short phialid with a false head. Macroconida were straight fussiform, pedicellate basal cell, 3-5 septate. Microconidia were abundant, ellipsoid or fussiform without or with 1-2 septa.

\subsection{Geographical Distribution}

Fusarium spp is distributed not only to tropical and temperate regions but these are also reported in harsh climatic conditions like desert, alpine and arctic areas (Nelson et al., 1994). Their widespread distribution may be due to their ability to colonize diverse ecological niches in most geographical areas of the world.

Pepper Fusarium wilt was first reported in New Mexico (Leonian, 1919), It was also reported from Pakistan (Kamal \& Moghal, 1968; Hafiz, 1986), Avery Island, Louisiana (Black \& Rivelli, 1990), Central Java (Agrios, 2005) and Spain (Serrano-Alonso et al., 2014). FOC is the major devastating and destructive disease, affecting production of pepper in Egypt (Attia \& Abada, 1994). In India, occurrence of Fusarium wilt in bell pepper and chilli has been reported in various parts of country and causes up to 25 per cent losses (Madhukar \& Naik, 2004). Naqvi (2004) reported 35 percent wilt incidence in many states of USA and it is also reported that after 30 days of soil infestation, Fusarium oxysporum kills 56\% chilli seedlings (Mona et al., 2012). The yield loss due to the disease is known to vary from 10-80 percent worldwide (Loganathan et al., 2013).

\subsection{Current Status of Fusarium Wilt in Ethiopia}

Currently hot pepper fusarium wilt is big agenda for researcher, Agricultural expertise at different level and Farmers having long experience in pepper production. There is variability among pepper wilt in district and region wise. Regarding the variation of hot pepper fusarium wilt, within and across districts, relatively higher incidence [maximum $\geq 50 \%$; 90.5\% (Alaba), 79.4\% (Meskan), 63.6\% (Mareko), 50\% (Dugda) and 50\% (Adama)] has been recorded in all districts of the Central Rift Valley of Ethiopia except Adami Tullu Jiddo Kombolcha districts which had a maximum HPFW incidence of 19.4\% (Gabrekiristos et al., 2020). Wilt disease caused by Fusarium is the leading one having wide distribution wherever pepper is produced in Ethiopia. The most recent report on pepper fusarium wilt at district level in Ethiopia indicated, $46.5 \%$ in Mareko, $46.0 \%$ in Alaba, $42.9 \%$ in Meskan, $40.0 \%$ in Adama, 30.9\% in Dugda and $15.1 \%$ in Admi Tullu Jiddo Kombolcha (Gabrekiristos et al., 2020). Wilt disease of hot pepper caused by Fusarium spp have been reported in Bako and Nejo areas (BARC, 2000). Fusarium wilt has been known to account the losses up to $80 \%$ around Dugda (Shimeles et al., 2007).

In Ethiopia relative yield loss of $68-71 \%$ was obtained due to the effect of fusarium wilt from un-treated Marako-fana variety (Teshome et al., 2012). Further more recent study by Shiferaw and Alemayehu (2014) indicated that the occurrence of fusarium wilt was the highest at Abeshge (55\%) followed by Halaba (41\%), Hawassa zuria (36\%), Dalocha (32\%) and Lanfro (30\%) and in other location mainly western Ethiopia (Assefa et 
al. 2015) reported $86.4 \%$ wilt incidence. This report indicates that there is variation in level of infection and wilt causing pathogens in different localities of Ethiopia. Wilt causing pathogen of pepper is common problem in Amhara Region now days (personal communication, 2018).

\subsection{Symptoms of Fusarium Wilt on Pepper}

Most of wilt causing pathogens including fusarium wilt of pepper have Primary and secondary symptom.FOC infects plant from roots and grow from inside towards the cortex (Beckman, 1987). Symptoms are quite variable but wilting of plant parts as a consequence of xylem dysfunction is the most conspicuous symptom of vascular wilt disease. The wilting symptoms appear as a result of severe water stress, mainly due to the vessel plugging/occlusion. Primary symptom of the pathogen is brown vascular discoloration followed by upward and inward rolling of the upper leaves and subsequently wilting of the plants is as secondary symptom (MacHardy \& Beckman, 1981; Rivelli, 1989).

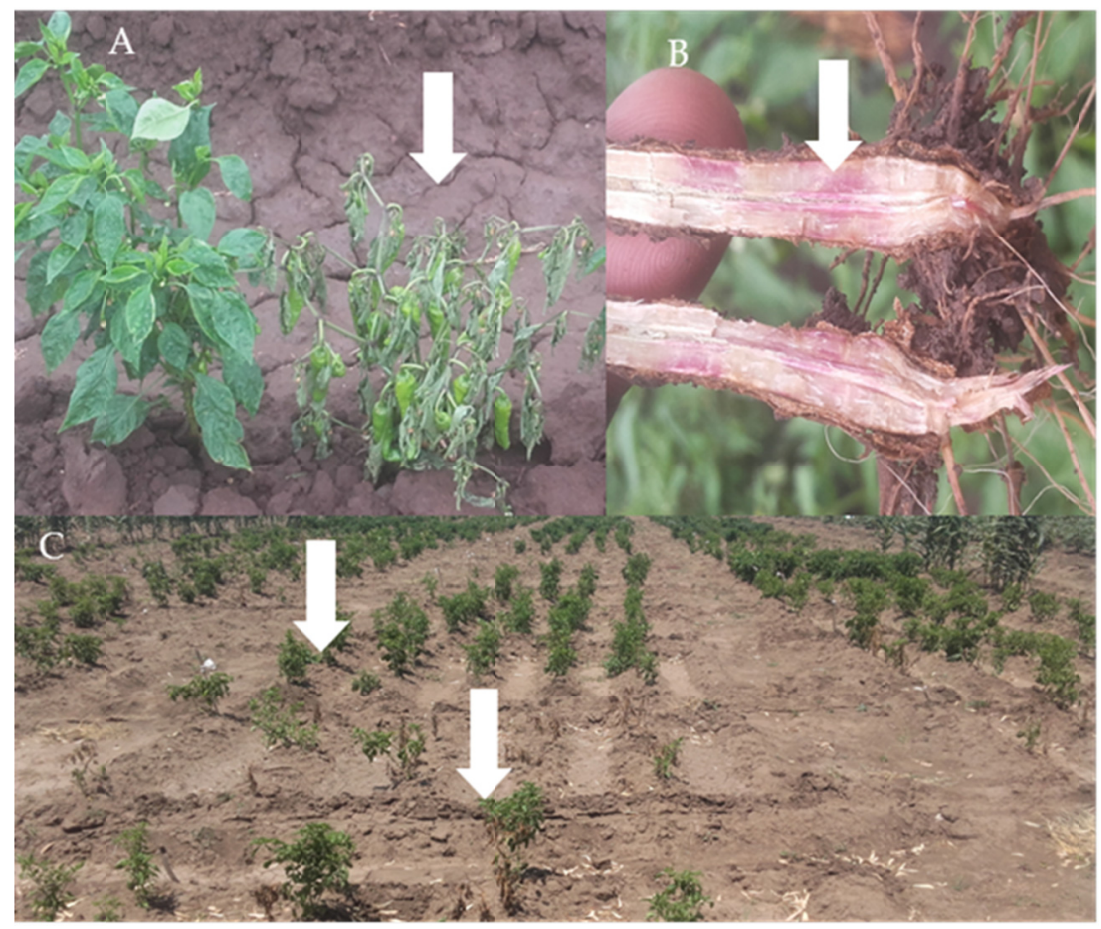

Figure 1. Symptom of hot pepper Fusarium wilt; A: wilted plant due to Fusarium wilt; B: stem discoloration, C: Severely infected plot due to FOC

Source: Endriyas (2018) (unpublished).

Symptoms of Fusarium wilt first appear as slight vein clearing on the outer portion of the younger leaves, followed by epinasty (downward drooping) of the older lower leaves. Slight yellowing of lower leaves and wilting of upper leaves followed by permanent wilting of entire plant and browning of the vascular tissue are the characteristic symptoms of the disease (Smith et al., 1988; Black \& Rivelli, 1990). The most common symptoms caused by $F$. oxysporum infection included leaf chlorosis, vascular discoloration, wilting of the plants, root rot, crown rot, stunting, wilting and death of the plants (Lefebvre \& Palloix, 1996). At the severe infection the lower leaves wilt and drop, which leads to decrease the number of leaf per stem this leads to bare stems.

\subsection{Ecology and Epidemiology}

Environmental conditions like temperature, spore density and water potential influence the germination of Fusarium conidia (Stakheev et al., 2011). Foc is a typical soil-borne pathogen and the fungus survives for long period of time in the soil in the form of chlamydospores (Garret, 1960). Fusarium spp. produces different types of spores, i.e., macro-conidia, micro-conidia and chlamydospores (Nelson et al., 1981), which act as asexual spore and help in survival of the pathogen. Spore production is triggered by the factors like nutrient sources, lights, metals, lipid signals and the chemistry of the plant host (Brodhagen \& Keller, 2006). The optimum growth of the genus Fusarium is found between 25 to $28{ }^{\circ} \mathrm{C}$, while the maximum growth is generally obtained at $28{ }^{\circ} \mathrm{C}$, 
inhibited above $33^{\circ} \mathrm{C}$ and not favored below $17{ }^{\circ} \mathrm{C}$ (Cook \& Baker, 1983). High temperature and high moisture plays a significant role in disease development (Sanogo, 2003). Fusarium wilt disease significance also varies with host susceptibility, pathogen virulence, soil type, and environmental conditions (Goldberg, 2010). The pathogen enters the plant through root tips and can remain viable in the soil for up to 30 years (Sally et al., 2006; Thangavelu et al., 2003). The mycelium grows in the xylem vessels where they cut off water supply resulting to wilting (Stephen et al., 2003). There is often an association of Fusarium wilt and nematode colonization where the nematodes provide entry route for the fungus. Enzymes may also facilitate Fusarium penetration into plant host (Babalola, 2010).

Infection and disease development in Fusarium wilt is favored by warm soil temperature and low soil moisture (Lewis, 2003). The disease tends to be most severe in sandy soils and generally less of a problem in heavier clay soils (Larkin et al., 2002) but in Ethiopia type of soil texture with high disease intensity was observed on the clay loam soil this might be due to high water holding capacity that may indirectly favor wilt causing pathogens in the area (Mekonnen et al., 2015). The effect of $\mathrm{pH}$ has been shown to influence the growth and sporulation of Fusarium spp. and most suitable pH level for growth of fungus was 5.0 and 6.0 (Gangadhara et al., 2004).

Table 2. Relationship between soil characteristics and fusarium wilt incidence, 2018

\begin{tabular}{lll}
\hline Soil Factor & Favoring condition & Reference \\
\hline Soil texture & Sandy soil & Larkin et al. (2002) \\
Soil temperature & 25 to $30{ }^{\circ} \mathrm{C}$ & Tu (1994) \\
Air temperature & 25 to $30{ }^{\circ} \mathrm{C}$ & Kumar et al. (2012) \\
Soil moisture & $20 \%$ & Sekhon and Singh (2007) \\
$\mathrm{pH}$ & 5.0 to 6.0 & Gangadhara et al. (2004) \\
\hline
\end{tabular}

\subsection{Disease Cycle}

Fusarium wilts are generally presumed to be monocyclic because, the disease does not exhibit plant-to-plant spread during the season (Egel \& Martyn, 2007). This is primarily because there are no propagules capable of dissemination to other plants to cause secondary infections that form above ground until very late in the season. There is some evidence that suggests some Fusarium wilts, for example, Fusarium wilt of tomato, may be a polycyclic disease capable of significant secondary spread during the season (Egel \& Martyn, 2007).The life cycles of most Fusarium wilts are similar and resemble that of the Fusarium wilt of tomato (Agrios, 2005). Like that of Verticillium wilt, the life cycle of Fusarium species can be divided into dormant (resting stage), parasitic and saprophytic stages when the host is absent (Beckman, 1987). The dormant stage comprises inhibition and germination of resting structures in soil. Report by Endriyas (2019), indicated that chlamydospore is formed in the petri-plate when there is scarcity of medium. Report by Garret (1960), indicates that fusarium wilt is extremely adaptable, variable and capable of long persistence in soil in the form of chlamydospores.

The parasitic stage comprises penetration, colonisation of the root cortex and endodermis, colonisation of the xylem of stems and leaves, symptom expression and, later on, death of the host.

Fusarium species enter the parasitic phase when germ-tube (Appressorium) of spore, penetrates the host through cracks formed by emerging lateral roots, wounds or at the root cap, root hairs or branch roots (Mandeel, 2007). Penetration process increases by certain hydrolysing enzymes secreted by Fusarium (Walter et al., 2009). Stover (1970) also reported that mycelial growth and cell wall degrading enzymes and toxins produced by the pathogen may contribute to vascular occlusion, which leads to the development of a systemic vascular disease in the host plants. There has been report by Morrell and Bloom (1981), on association of Fusarium wilt and nematode colonisation, where the nematodes provide a potential entry point (wound) for the fungus.

\subsection{Spread Method of Pepper Fusarium Wilt}

Depending on the species, Fusarium can be dispersed by one of several means including the movement of contaminated seed, corms and bulbs; water-borne and wind-borne soil; and in infected cuttings and transplants. This pathogen spreads in two basic ways: it spreads short distances by water splash, and by planting equipment, and long distances by infected transplants and seeds. Spores are disseminated by the wind, in ground water, or by movement of the contaminated soil, stake, or equipment (Jaywant, 2016). 


\section{Host Range of Fusarium oxysporum}

Fusarium oxysporum is the most widespread and destructive species causing vascular wilt diseases on many plants including pepper (Mushtaq \& Hashmi, 1997).The pathogen is known to cause severe losses to a large array of agricultural crops such as tomato (Lycopersicon esculentum L.), banana (Musa acuminata Colla), cabbage (Brassica oleracea var. capitata L.), pea (Pisumsativum L.), chickpea (Cicer arietinum L.), water-melon [Citrullus lanatus (Thunb.) (Matsum \& Nakai)], cotton (Gossypium hirsutum L.) and spinach (Hungerford, 1923; Nelson, 1981; Padwick, 1940). Other commercially important plants affected include basil, beans, carnation, chrysanthemum, peas and watermelon. Woody ornamentals are infected, but are usually not killed by Fusarium wilt alone. Palms, however, are the exception, and there are many species that can die from F. oxysporum infection (Dreistadt \& Clark, 2004). Pathogenic strains within the species have a limited host range, and strains with similar or identical host ranges are assigned to the same formae speciales (Armstrong, 1981). Fusarium oxysporum was found in association with the wilt disease of C. annuum (Kraft \& Papavizas, 1983; Kucuk \& Kivanc, 2003; Siddiqui \& Akhtar, 2007). The high level of host specificity of pathogenic strains in F. oxysporum led to the development of the "formae specials" concept to enable better differentiation of these morphologically similar strains (PADIL, 2011).

\section{Mechanism of Infection}

Once Foc is inside the plant, the mycelium grows through the root cortex intercellulary and when it reaches the xylem, it invades the vessels through the xylem's pits (Agrios, 1988). Due to the growth of the fungus within the plant's vascular tissue, the plant's water supply is greatly affected and this results the leaves' stomata to close, the leaves wilt, and the plant eventually dies. It is at this point that the fungus invades the plant's parenchymatous tissue, until it finally reaches the surface of the dead tissue, where it sporulates abundantly. The resulting spores which on their turn act as new inoculum for further spread of the fungus (Agrios, 1988). Vascular wilt pathogens satisfy their nutritional requirements by efficiently acquiring the scarce nutrients available in the xylem sap, by enzymatic digestion of host cell walls, by invading neigh-boring cells, or by inducing nutrient leakage from surrounding tissues (Divon et al., 2005; Mobius \& Hertweck, 2009; Klosterman et al., 2011). Nitrogen is one of the limiting nutrients in the xylem sap for vascular wilt pathogens (Divon et al., 2005). The fungus can invade a plant with its sporangial germ tube or mycelium by invading plant roots, through wounds or directly through the root tip or at the formation point of lateral roots (Koste, Thomma, \& Bart, 2013).

\section{Management Options}

Attempts to contain and minimize the diseases caused by Fusarium wilt has been made by using various kinds of control measures in the greenhouse and the field conditions. An important point to remember is that the control procedures should be applied before planting because there are no rescue treatments. Moreover, once the disease becomes existent, an important part to minimize the losses is to avoid stress on the plants (Ozbay et al., 2004). Wilt causing pathogens can be managed by cultural, biological, chemical means and by screening of germplasms/lines for resistance (Mamta et al., 2012). It is also reported that effective means of controlling F.oxysporum include: disinfestation of the soil and planting material with fungicidal chemicals, crop rotation with non-hosts of the fungus, or by using resistant cultivars (Jones et al., 1982; Smith et al., 1988). It is observed that application of fungicides is a quick method to manage Fusarium wilt disease but fungicides are not eco-friendly and adversely affected human beings, microorganisms and environment with its toxic residues (Parker et al., 1985) and also, it has been observed that pathogen has developed genetic resistance against the fungicides (Sela-Buurlage et al., 2001). In Ethiopia the use of crop rotation, fallowing, resistant varieties, and in the severe case application of chemicals is stated options to manage pepper fusarium wilt (EARO, 2004).

\subsection{Host Resistance}

Host plant resistance has been a choice in all crop improvement programs and it is perhaps the best method available to tackle soil-borne diseases.Use of genetic resistance for the management of pepper diseases in general and fusaruim wilt in particular is the simplest and most cost-effective method (Sanogo, 2003). When dealing with soil-borne diseases, cultivar resistance is the preferred method for control because it can be highly effective and is the least damaging to the environment (Fravel et al., 2003).

Research in Ethiopia by Endriyas et al. (2020) indicated that, performance of ACC 80061 and Oda Haro under infection with the highly potent isolate 4DGK was promising. In Ethiopia Significantly, $(\mathrm{P} \leq 0.05)$ lowest wilt (4.66\%) incidence and AUDPC (279\%-day) were obtained by integration of the moderately resistant variety Oda-haro with solarization-fungicide-flat seedbed (Teshome et al., 2012). This finding is good indication for the screening of hot pepper cultivar for their reaction to fusarium wilt. Thus, currently available pepper cultivars should be tested for the identified wilt causing pathogens (Mekonnen et al., 2015). 
Screening of genotypes/hybrids is an important aspect in resistant breeding program for the management of soil-borne diseases worldwide, especially against Fusarium wilt disease of economically important several crops (Ahmed et al., 1994; Nayeema et al., 1995; Madhukar et al., 2002; Naik et al., 2008; Morid et al., 2012; Purna, 2013; Kumar et al., 2014; Shafique et al., 2015). Studies by Mamta et al. (2012) indicates that, Among thirty varieties screened, only two varieties CO-4 and DLC-352 were found 100\% resistant, while five varieties, viz., Ajeet-3, DLC-524, F-112-5-83, KCS-2013 and Nun-2060 of hot pepper were moderately resistant (83.34). Jaywant et al. (2017) screened chili genotype against fusarium wilt and cultivar CO-4 showed resistant reaction (6.67\% wilt), however, six cultivars viz., HC-1, GC-1, GC-2, Kashi Gaurav, Ajeet-6 and DKC-8 were moderately resistant (15.56 to 24.44\% wilt), whereas, three cultivars viz., Pant C-1, Punjab Lal, Kashi Sinduri were moderately susceptible (33.33 to $48.99 \%$ wilt) and the remaining twelve cultivars were either susceptible ( $>50 \%$ wilt) or highly susceptible ( $>75 \%$ wilt), which could not survive against the pathogen.

\subsection{Use of Antagonists}

The different mechanism of bio-control of plant pathogens using antagonists may be through competition for space and food or by stimulating host plant by inducing tolerance or resistance to the pathogen, or antibiosis that means production of low molecular fungi toxic compounds or enzymes (Matar et al., 2009). Singh and Zaidi (2002) reported that some bioagent enhanced the growth of some crop species. Use of antagonistic species is environmentally oriented, ecologically and economically sound method as depicted in benefit/cost ratio and expresses less environmental haphazard and toxicity as compared to other conventional disease controlling methods. Now a day's biological control is considered as an important approach of agricultural biotechnology in recent years for controlling many fungal plant pathogens (Zaher et al., 2013, Abada \& Eid, 2014).

In Ethiopia, in vitro antagonistic evaluation to manage 4DGK isolate results; $T$. Asperellum provided the highest growth inhibition $(85.2 \%)$ followed by T.viride, T.longibiracher and T. harzianum, which reduced mycelial growth up to $80.4 \%, 77.6 \%$ and $77.3 \%$, respectively (Endriyas, 2020 ).

Fusarium genera were diverse in species and even some strains of Fusarium oxysporum are not pathogenic and may even antagonize the growth of pathogenic strains and can be used as biological agents (Fravel et al., 2003). Singh and Zaidi (2002) reported that root dipping in antagonists (i.e., Trichoderma spp.) suspension $\left(10^{6} \mathrm{cfu} / \mathrm{ml}\right)$ not only reduced the rate of disease severity but also enhanced the seedling growth in rice, tomato, brinjal, chilli and capsicum which is double advantage. Sahi and Khalid (2007) reported that among the Trichoderma species, T. viride showed the best performance (62\%), followed by T. harzianum (36\%), T. aureoviride (24\%), T. koningii (18\%) and T. pseudokoningii (6\%) in reducing the colony growth of F. oxysporum in sweet pepper (Capsicum annuum). Oyetunji and Salami (2011) observed the effect of arbuscular mycorrhiza (AM) (i.e., Glomus mosseae) and Trichoderma koningii as antagonists against Fusarium wilt of pepper. Amaresan et al. (2014) investigated the antagonistic potential of endophytic bacteria against Fusarium oxysporum and the results revealed that most of the isolates showed antagonistic activity against F.oxysporum. A combination of T. herziamnum, T. asperellum and $T$. virens has the highest capacity of control (80-87\%), followed by a binary combination of Trichoderma species (79-82\%), while T. virens alone has the lowest control rate of 65\% (Akrami \& Yousaefi, 2015).

\subsection{Botanicals}

Botanicals show antifungal activity against a large number of fungal diseases (Javaid \& Rauf, 2015). The plant extracts provide an effective measure for Fusarium wilt disease management and it can be one component of integrated disease management. The fungitoxic properties of different plant extracts against Fusarium spp. have been investigated by Shivpuri et al. (1997) and the results indicated that the maximum inhibition (80-85\%) of the pathogen was observed with Allium sativum and Allium cepa. Singh and Kumar (2011) reported that the soil treatments with botanicals viz., Mentha arvensis significantly reduced the Fusarium wilt of Chrysanthemum with the maximum (70.0\%) disease control, followed by Tagetus patula $(61.0 \%)$ and Datura stramonium $(50.0 \%)$. The botanicals like garlic oil was highly effective (100\%) even at 5 per cent concentration, whereas, neem oil was comparatively less effective $(59.63 \%)$ at 5 percent concentration (Jaywant, 2016). It is also reported that mustard oil (93.75\%) and Datura $(90.94 \%)$ reduce the growth of fusarium wilt in vitro. Among other management options use of botanical can be a solution for wilt causing pathogens and garlic shows $100 \%$ control of fusarium wilt which should get due attention.

\subsection{Fungicides}

Use of pesticides is an important tool for managing different diseases including soil-borne pathogens. Various systemic and non-systemic fungicides have been reported effective against the fungus. Evaluation of carbendazim and benomyl under in vitro and in vivo by soil drenching at different depths viz., 5,10 and $15 \mathrm{~cm}$ (Naik et al., 2007) which resulted maximum inhibition of Fusarium wilt disease in pepper. Sharma et al. (2002) 
studied inhibitory effect of carbendazim, copper oxychloride, captan and metalaxyl + mancozeb (Ridomil) against $F$. oxysporum and other pathogens associated with wilt disease of bell pepper under in vitro conditions and reported that carbendazim (Bavistin) and captan completely inhibited the growth of fungus. Fungicides such as Ridomil Gold, Carbandazim, Metalaxyl and Mancozeb are being used to control the Fusarium wilt (Sitara \& Hasan, 2011). The increased use of pesticides in past has led to several problems, such as environmental degradation, health hazards, pest resistance and decrease in population of beneficial insects (Groenewald, 2006). So, pesticide should be used in safe and care method to decrease the hazard occurred on human and environment.

To manage soil borne pathogens through fungicide is not practiced in Ethiopia. Some effort was made to in vitro evaluate fungicides having different group of active ingredient (Gabrekiristos \& Ayana, 2020). The recent finding by Gabrekiristos and Ayana (2020) indicates, URGI 75\% WP, Nativo SC 300 and Twinstar75 WG led to $98.8 \%, 94.0 \%$ and $92.3 \%$ mycelia growth inhibition, respectively (Gabrekiristos \& Ayana, 2020). This can be good news to Ethiopian hot pepper producer. The Master isolate, 4DGK were used since the isolate showed as highly pathogenic to Marako Fana variety and some fungicides are not effective in inhabiting. So, Mancodex Super 72 WP (2.9\%) and Agro Laxyl MZ 63.5 WP (6.5\%) that was not effective in inhibiting the mycelial growth of hot pepper fusarium wilt (Gabrekiristos \& Ayana, 2020). Gabrekiristos stated that, URGI 75\% WP (Carbendazim and Mancozeb; $120+640 \mathrm{~g} / \mathrm{Kg}$ ), inhibit in vitro mycelial growth of FOC and it can be use to evaluate in vivo.

\section{Conclusions and Future Prospects}

Hot pepper serves as important sources of income to smallholder farmers and as exchange earning commodity in Ethiopia. It is a rich source of vitamin A, C and E. This crop is grown in many regions of Ethiopia and is an important ingredient for some of the most famous dishes of Ethiopian cuisine and besides its popularity; pepper can be used as raw material for extraction of oleoresin capsicum and paprika by the Ethiopian Spice Extraction Factory.

It is summarized that, in Ethiopia this high value crop is constrained by powdery mildew, Phytophthora leaf blight, Fusarium wilt, bacterial leaf spot, bacterial wilt, bacterial soft rot and pepper motile virus. Wilt disease caused by Fusarium oxysporum f.sp. Capsici is the top pathogen and reported from where ever pepper is produced in the country. Fusarium wilt is the major constraint causing high damage in Oromia, South Nation Nationalities and peoples and Amhara regions of Ethiopia. Within and across districts, relatively higher incidence [maximum $\geq 50 \%$; 90.5\% (Alaba), 79.4\% (Meskan), 63.6\% (Mareko), 50\% (Dugda) and 50\% (Adama)] has been recorded in all districts. The occurrence of hot pepper fusarium varies based on host susceptibility, virulent pathogen and environmental condition.

This review concludes that, wilt causing pathogens can be managed by cultural, biological, chemical and by Screening of germplasms/lines for resistance. Endriyas et al. reported that, performance of ACC 80061 and Oda Haro under infection with the highly potent isolate 4DGK was promising. In Ethiopia, in vitro antagonistic evaluation to manage 4DGK isolate results; T. Asperellum provided the highest growth inhibition (85.2\%) followed by $T$. viride, $T$. longibiracher and $T$. harzianum, which reduced mycelial growth up to $80.4 \%, 77.6 \%$ and $77.3 \%$, respectively. Gabrekiristos stated that, URGI 75\% WP (Carbendazim and Mancozeb), inhibit in vitro mycelial growth of FOC up to $98.8 \%$ and it can be used after evaluating in vivo.

It is recommended that, hot pepper materials should pass through quarantine system to the county. Varietal screening should be intensively done to replace susceptible one and Country wide survey is important for early detection. Integrated disease management strategies should have to be developed by using compatible management options. Grafting hot pepper for control of wilt causing pathogens is common in European countries, which should have to be practiced in Ethiopia. Studies on epidemiological element should have to be conducted to easily break the wilt epidemics.

\section{References}

Abada, K. A., \& Eid, Kh. E. (2014). A Protocol suggested for management of canta-loupe downy mildew. American Journal of Life Sciences, 2(3), 1-10. https://doi.org/10.11648/j.ajls.s.2014020602.13

Abraham, A., Alemayehu, W., \& Kanko, C. (2016). Performance Evaluation of Elite Hot Pepper (Capsicum Annum) Varieties for Yield and Yield Components at Derashea, South Eastern Ethiopia. International Journal of Research Granthaalayah, 4(12), 95-100. https://doi.org/10.5281/zenodo.222635

Agrios, G. N. (1988). Plant Pathology (3rd ed., p. 803). New York, USA: Academic Press, Inc. https://doi.org/ 10.1016/B978-0-12-044563-9.50005-0 
Agrios, G. N. (2005). Plant Pathology (5th ed., p. 922). Burlington, USA: Elsevier Academic Press.

Ahmed, N., Tanki, M. I., \& Mir, N. M. (1994). Screening of advance breeding lines of chilli and sweet and hot pepper cultivars against Fusarium wilt. Pl. Dis. Res., 9(2), 153-154.

Akrami, M., \& Yousefi, Z. (2015). Biological controls of Fusarium wilt of tomato (Solanum lycopersicum) by Trichoderma spp. as antagonist fungi. Biological Forum - An International Journal, 7(1), 887-892.

Amaresan, N., Jayakumar, V., \& Thajuddin, N. (2014). Isolation and characterization of endophytic bacteria associated with chilli (Capsicum annuum L.) grown in coastal agricultural ecosystem. Indian Journal of Biotechnology, 13, 247-255.

Armstrong, G. M., \& Armstrong, J. K. (1981). Formae speciales and races of Fusarium oxysporum causing wilt disease. In P. E. Nelson, T. A. Toussoun \& R. J. Cook (Eds.), Fusarium: Disease, biology, and taxonomy (pp. 391-399). University Park, PA: Pennsylvania State University Press.

Assefa, W., Dawit, W., Lencho, A., \& Hunduma, T. (2015). Assessment of wilt intensity and identification of causal fungal and bacterial pathogens on hot pepper (capsicum annuum L.) in Bako Tibbe and Nonno districts of West Shewa Zone, Ethiopia. Intl. J. Phytol., 4(1), 21-28. https://doi.org/10.33687/phytopath. 004.01.0972

Attia, M. F., \& Abada K. A. (1994). Control of wilt and root-rot of pepper. Proceedings of 7th Congress of Phytopathology, Cairo, Egypt (pp. 397-409).

Babalola, O. O. (2010a). Pectinolytic and Cellulolytic enzymes enhance Fusarium compactum virulence on tubercles infection of Egyptian broomape. International Journal of Microbiology, Article ID: 273264. https://doi.org/10.1155/2010/273264

BARC (Bako Agricultural Research Center). (2000). Progress Report 1999/2000. Bako Agricultural Research Center, Crop Protection Research Division.

Beckman, C. H. (1987). The nature of wilt diseases of plants (p. 175). American Phytopathological Society, USA.

Berke, T. (2002). The VB KL Asian Vegetable Research Development Canter Pepper Project.

Beyene, T., \& David, P. (2007). Ensuring Small Scale Producers in Ethiopia to Achieve Sustainable and Fair Access to Pepper Market. Uganda Journal of Agriculture, 3(2), 113-119.

Black, L., \& Rivelli, V. (1990). Fusarium wilt of pepper in Louisiana. In E. K. Delaware \& S. A. Johnson (Eds.), Proceeding 10th National Pepper Conference, June 25-27, 1990, University of Delaware, Wilmington (p. 44)

Booth, C. (1971). The Genus Fusarium (p. 237). Commonwealth Mycological Institute, Kew Surrey, England.

Bos, L. (1974). Virus diseases of pulses and other crops in Ethiopia (p. 32). Food and Agriculture Organization of the United Nations, Rome.

Bosland, P. W., \& Votava, E. J. (2000). Peppers, Vegetables and Spices Capsicum (p. 198). CABI Publishing, New York

Brodhagen, M., \& Keller, N. P. (2006). Signalling pathways connecting mycotoxin production and sporulation. Molecular Plant Pathology, 7(4), 285-30. https://doi.org/10.1111/j.1364-3703.2006.00338.x

Burgess, L. W. (1981). General ecology of the Fusaria. In P. E. Nelson, T. A. Toussoun, \& R. J. Cook (Eds.), Fusarium: Diseases, Biology, and Taxonomy (pp. 225-235). University Park, PA: Pennsylvania State Univeristy Press.

Cook, R. J., \& Baker, K. F. (1983). The nature and practice of biological control of plant pathogens (p. 539). American Phytopathological Society, St. Paul, MN, USA.

CSA (Central Statistical Agency). (2018). Agricultural Sample Survey (September-December, 2019/2020). The Federal Democratic Republic of Ethiopia.

Divon, H., Rothan, H., Denoyes, B., Davydov, O., Dipietro, A., \& Fluhr, R. (2005). Nitrogen-responsive genes are differentially regulating dinplanta during Fusarium oxysporum f. sp. lycopersici infection. Molecular Plant Pathology, 6, 459-470. https://doi.org/10.1111/j.1364-3703.2005.00297.x

Dreistadt, S. H., \& Clark, J. K. (2004). Pests of Landscape Trees and Shrubs: An Integrated Pest Management Guide (pp. 233-34). ANR Publications. 
EARO (Ethiopian Agricultural Research Organization). (2000). Plant protection research strategy. EARO, Addis Ababa.

Egel, D. S., \& Martyn, R. D. (2007). Fusarium wilt of watermelon and other cucurbits. The Plant Health Instructor. https://doi.org/10.1094/PHI-I-2007-0122-01

Endriyas, G. (2019). Distribution of Hot Pepper Fusarium Wilt (Fusarium Oxysporium F.sp. capsici) and Evaluation of Host Resistance and Biocontrol Agents against the Pathogen in the Central Rift Valley of Ethiopia (MSc thesis, Melkassa Agricultural Research Center, Ethiopian Institute of Agricultural Research, Adama, Ethiopia).

FAOSTAT. (2015). FAO Statistics Division 2012. Retrievd from https://www.faostat.fao.org

FAOSTAT. (2017). FAO Statistics Division 2014. Crops/World Regions/Production Quantity/Chillies and Peppers, Green and Dried from Pick List. Retrievd from https://www.faostat.fao.org

Fekadu, D., \& Dandena, G. (2006). Status of Vegetable Crops in Ethiopia. Ugandan Journal of Agriculture, 12(2), 26-30.

Fikre, L. O. (2006). Biochemical, Pathological and Genetic Characteristics of Strains of Ralstonia solanacearum (Smith) from Ethiopia and Biocontrol of Ralstonia solanacearum with Bacterial Antagonists (PhD Dissertation, Gottfried Leibniz University Hannover).

Fravel, D., Olivain, C., \& Alabouvette, C. (2003). Fusarium oxysporum and its biocontrol. New Phytologist, 157, 493-502. https://doi.org/10.1046/j.1469-8137.2003.00700.x

Gabrekiristos, E., \& Ayana, G. (2020). In Vitro Evaluation of Some Fungicides against Fusarium oxysporum the Causal of Wilt Disease of Hot Pepper (Capsicum annum L.) in Ethiopia. Adv Crop Sci Tech, 8, 443. https://doi.org/10.35248/2329-8863.20.8.443

Gabrekiristos, E., Teshome, D., \& Ayana, G. (2020). Distribution and Relative Importance of Hot Pepper Fusarium Wilt (Fusarium oxysporium f.sp. capsici) and Associated Agronomic Factors in the Central Rift Valley of Ethiopia. Adv Crop Sci Tech, 8, 437.

Gangadhara, N. B., Nagaraja, R., Basavaraja, M. K., \& Krishna, N. R. (2004). Variability studies of Fusarium oxysporum f. sp. vanillae isolates. International Journal of Science and Nature, 1(1), 12-16.

Garret, S. D. (1960). Inoculum potential. In J. G. Horsfall, \& A. E. Dimond (Eds.), Plant Pathology: An Advanced Treatise (Vol. 3, pp. 23-56). Academic Press, New York.

Goldberg, N. P. (2010). Verticillium Wilt of Chile Peppers. College of Agricultural, Consumer and Environmental Sciences on the World Wide.

Groenewald, S. (2006). Biology, pathogenicity and diversity of Fusarium oxysporum f.sp. cubense (p. 158, M.Sc. Thesis, University of Pretoria, South Africa).

Hungerford, C. W. (1923). A Fusarium wilts of spinach. Phytopathology, 13, 205-209.

Irfan, Y. S., \& Khalid, A. N. (2007). In vitro biological controls of Fusarium oxysporum causing wilt in Capsicum annuum. Mycopathology, 5(2), 85-88.

Jack, H. E., Syndi, B., Krystle, C., \& Axiom, C. (2006). How to grow a tomato plant under different fertility regimes (pp. 1-10). Wiki How.

Javaid, A., \& Rauf, S. (2015). Management of basal rot disease of onion with dry leaf biomass of Chenopodium album as soil amendment. International Journal of Agriculture and Biology, 17, 142-148.

Jaywant, K. S. (2016). Pathogenic Variability and Management of Fusarium wilt of Chilli (Capsicum annuum L.) (p. 95, PhD Thesis in plant pathology in College of Agriculture CCS Haryana Agricultural University Hisar).

Jaywant, K., Manoj, K., Anil, K., \& Naresh, M. (2017). Screening of Chilli Cultivars against Fusarium Wilt of Chilli (Capsicum annuum L.), International Journal of Agricultural Science and Research, 7(1), 235-240.

Jones, J. P., Jones, J. B., \& Miller, W. (1982). Fusarium wilt on tomato. Plant Pathology Circular No. 237. Fla. Dept. Agric. \& Consumer Serv., Div. of Plant Industry.

Kamal, M., \& Moghal, S. M. (1968). Studies on plant disease of south west (p. 207). Pakistan Agriculture College Tandojan. 
Kassahun, S., Tariku, H., \& Mekonnen, A. (2016). Characterization and Evaluation of Hot Pepper (Capsicum annuum L.) Cultivars against Bacterial Wilt Disease (Ralstonia solanacearum). Pyrex Journal of Microbiology and Biotechnology Research, 2(3), 22-29.

Kelaniyangoda, D. B., Salgadoe, A. S. A., Jayasekera, S. J. B. A., \& Gunarathna, R. M. (2011). Wilting of bell pepper (Capsicum annuum L.) causal organism isolation and successful control approach. Asian Journal of Plant Pathology, 5(4), 155-162. https://doi.org/10.3923/ajppaj.2011.155.162

Kloster Man, S. J., Subbarao, K. V., Kang, S., Veronese, P., Gold, S. E., \& Thomma, B. P. H. J. (2011). Comparative genomics yields in sightsintoniche adaptation of plant vascular wilt pathogens. PLoS Pathol., 7, 1002137. https://doi.org/10.1371/journal.ppat.1002137

Korobkon, A., Tegegn, T., \& Dilbo, C. (1986). Chemical control of bacterial leaf spot of hot pepper (Capsicum annuum L.) Caused by Xanthomonas campestris pv. vesicatoria. Scientific Phytopathological Laboratory (SPL) Progress Report for the Period 1985/86 (pp. 92-199).

Koste, A. Y., Thomma, J., \& Bart, P. H. (2013). The xylem as battle ground for plant hosts and vascular wilt pathogens. Frontiers in Plant Science, 4(10), 00097. https://doi.org/10.3389/fpls.2013.00097

Kraft, J. M., \& Papavizas, G. C. (1983). Use of host resistance Trichoderma and fungicides to control soil borne diseases and increase seed yields of peas. Plant Diseases, 67, 1234-1237. https://doi.org/10.1094/ PD-67-1234

Kucuk, C., \& Kivanc, M. (2003). Isolation of Trichoderma spp. and determination of their antifungal, biochemical and physiological features. Turkish Journal Biology, 27, 247-253.

Kumar, M., Tripathi, U. K., Tomer, A., Kumar, P., \& Singh, A. (2014). Screening of linseed germplasm for resistance/tolerance against Fusarium oxysporum f.sp. lini (Bolley) disease. Journal of Plant Pathology and Microbiology, 5, 235. https://doi.org/10.4172/2157-7471.1000235

Kumar, S., Singh, J., Biswas, S. K., Prem, N. P., \& Dabas, M. R. (2012). Effect of culture media, temperature, $\mathrm{pH}$ and host range on the growth of Fusarium oxysporum f. sp. capsici. Journal of Mycopathological Research, 50(1), 73-76.

Larkin, P., \& Fravel, D. R. (2002). Effects of varying environmental conditions on biological control of Fusarium wilt of tomato by Non-pathogenic Fusarium spp. American Journal of Phytopathology. USDA-ARS, MD. https://doi.org/10.1094/PHYTO.2002.92.11.1160

Lefebvre, V., \& Palloix, A. (1996). Both epistatic and additive effects of QTLs are involved in polygenic induced resistance to disease: A case study, the interaction pepper- Phytophthora capsici Leonian. Theor. Appl. Genet., 93, 503-511. https://doi.org/10.1007/BF00417941

Leonian, L. H. (1919). Fusariums wilt of Chile pepper. New Mexico Agricultural Experimental Station Technical Bulletin (p. 121).

Lewis, J. (2003). Tomato notes. News for Missouri Garden, Yards and Resources (Vol. 9, No. 8). Missouri Environment and Garden.

Loganathan, M., Venkatara, V., Saha, S., Sharma, B. K., Tirupathi, S., \& Verma, M. K. (2013). Morphological, cultural and molecular characterizations of Fusarium wilt infecting tomato and chilli. National Symposium on Abiotic and Biotic Stress Management in Vegetable Crops, Indian Society of Vegetable Science, IIVR, Varanasi.

MacHardy, W. E., \& Beckman, C. H. (1981). Vascular wilt Fusaria: Infections and Pathogenesis. In P. E. Nelson, T. A. Toussoun, \& R. J. Cook (Eds.), Fusarium: Diseases, Biology and Taxonomy (pp. 365-390). The Pennysylvania State University Press, University Park and London.

Madhukar, H. M., \& Naik, M. K. (2004). Evaluations of bioagents against Fusarium wilt of chilli (Capsicum annuum var. annuиm) (p. 540). Proceeding 15th International Plant Protection Towards 21 st Century Held in Beijing, China.

Madhukar, H. M., Naik, M. K., \& Patil, M. G. (2002). Evaluation of chilli genotypes and bioagents against Fusarium wilt of chilli. National Symposium on Crop Protection and WTO an Indian Scenario, CPCRI, Kassargod.

Mamta, J., Rashmi, S., Anil, K. S., \& Anil, P. (2012). Screening of Resistant Varieties and Antagonistic Fusarium oxysporum for Biocontrol of Fusarium Wilt of Chilli. Plant Pathology \& Microbiology, 3(5). https://doi.org/ $10.4172 / 2157-7471.1000134$ 
Mandeel, Q. A. (2007). Modeling competition for infection sites on roots by nonpathogenic strains of Fusarium oxysporum. Mycopathologia, 163(1), 9-20. https://doi.org/10.1007/s11046-006-0080-3

MARC (Melkassa Agricultural Research Center). (2004). Progress Report Addis Ababa.

Matar, S. M., El-Kazzaz, S. A., Wagih, E. E., Diwany, A. I., Moustafa, H. E., Abo-Zaid, G. A., Abd-Elsalam, H. E., \& Hafez, E. E. (2009): Antagonistic and inhibitory effect of Bacillus subtilis against certain plant pathogenic fungi, I. Biotechnology, 8(1), 53-61. https://doi.org/10.3923/biotech.2009.53.61

Mengistu, H. (1994). In E. Herath, \& D. Lemma (Eds.), Research on vegetable diseases in Ethiopia (pp. 209-216). Proceeding of 2nd National international Horticultural Work Shop of Ethiopia, December 1-3, 1992, Addi Ababa, IAR/FAO.

Mobius, N., \& Hertweck, C. (2009). Fungal phytotoxins as mediators of virulence. Curr. Opin. Plant Biology, 12, 390-398. https://doi.org/10.1016/j.pbi.2009.06.004

Mona, M. M., Ashour, A. M. A., Abdel-Kader, M. M., El-Mohamady, R, \& Abdel-Aziz A. (2012). In Vitro Evaluation of Some Fungicides Alternatives against Fusarium Oxysporum the Causal of Wilt Disease of Pepper (Capsicum annum L.). International Journal of Agriculture and Forestry, 2(2), 70-77. https://doi.org/10.5923/j.jiaf.20120202.11

Moretti, A. N. (2009). Taxonomy of Fusarium genus, a continuous fight between lumpers and splitters. Proceedings of Natural Science Matica Srpska Novi Sad, 117, 7-13. https://doi.org/10.2298/ZMSPN 0917007M

Morid, B., Hajmansoor, S., \& Kakvan, N. (2012). Screening of resistance genes to Fusarium root rot and Fusarium wilt diseases in tomato (Lycopersicon esculentum) cultivars using RAPD and CAPs markers. European Journal of Experimental Biology, 2(4), 931-939.

Morrell, J. J., \& Bloom, J. R. (1981). Influence of Meloidogyne incognita on Fusarium wilt of tomato at or below the minimum temperature for wilt development. Journal of Nematology, 1(1), 57-60.

Mushtaq, M., \& Hashmi, M. H. (1997). Fungi associated with wilt disease of Capsicum in Sindh, Pakistan. Pakistan Journal of Botany, 29(2), 217-222.

Naik, M. K., Devika Rani, G. S., \& Madhukar, H. M. (2008). Identification of resistance sources against wilt of chilli (Capsicum annuum L.) resistance caused by Fusarium solani (Mart.) Sacc. Journal of Mycopathological Research, 46(9).

Naik, M. K., Madhukar, H. M., \& Devika Rani, G. S. (2007). Evaluation of fungicides against Fusarium solani, the causal agent of wilt of chilli. Vegetable Science, 34(2), 173-176.

Naqvi, S. A. M. H. (2004). Diseases of fruit and vegetables. In P. D. Roberts, S. Adkins, K. Pernezny, \& J. B. Jones (Eds.), Diseases of pepper and their management (Vol. 2, pp. 333-387). Kluwer Academic Publishers, the Netherlands.

Nayeema, J., Ahmed, N., Tanki, M. I., \& Das, G. M. (1995). Screening of hot pepper germplasm for resistance to Fusarium wilt (F. pallidoroseum (Cook) Sacc.). Capsicum Egg Plant Newsletter, 14, 68-71.

Nelson, P. E., Dignani, M. C., \& Anaissie, E. J. (1994). Taxonomy, biology, and clinical aspects of Fusarium species. Clinical Microbiology Reviews, 7(4), 479-504. https://doi.org/10.1128/CMR.7.4.479

Nelson, P. E., Toussoun, T. A., \& Cook, R. J. (1981). Fusarium: Diseases Biology and Taxonomy (p. 457). Pennsylvania State University Press, University Park, Pennsylvania, USA.

Ortoneda, M., Guarro, J., Marta, P. M., Caracuel, Z. M., Roncero, I. G., Mayayo, E., \& Antonio, D. P. (2004). Fusarium oxysporum as a multi host model for the genetic 76 dissection of fungal virulence in plants and mammals. Infect Immun., 72(3), 1760-1766. https://doi.org/10.1128/IAI.72.3.1760-1766.2004

Oyetunji, O. J., \& Salami, A. O. (2011). Study on the control of Fusarium wilt in the stems of mycorrhizal and Trichoderma inoculated pepper (Capsicum annuum L.). Journal of Applied Biosciences, 45, 3071-3080.

Ozbay, N., \& Newman, E. S. (2004). Effect of T. harzianum strains to colonize tomato roots and improve transplant growth. Pakistan Journal of Biological Sciences, 7, 253-257. https://doi.org/10.3923/pjbs. 2004.253.257

PADIL (Pests and Diseases Image Library). (2011). Fusariums wilt of chicken pea. Retrieved from http://old.padil.gov.au/pbt/index.php?q=node/15andpbtID $=160$ 
Padwick, G. W. (1940). The genus Fusarium III: a critical study of the fungus causing wilt of gram (Cicer arietinum L.) and of the related species of the subsection Orthocera, with special relation to the variability of key characteristics. Indian Journal of Agricultural Science, 10(3), 241-284.

Parker, C. A., Ruvira, A. D., Moore, K. J., \& Wong, P. T. W. (1985). Ecology and Management of Soil-borne Plant Pathogens. APS Press, St. M. N. Paul.

Purna, R. (2013). Screening of chilli germplasms against Fusarium wilt and determination of their genetic variation through RAPD marker (p. 72, M.Sc. Thesis, Bangladesh Agricultural University, Mymensingh).

Rodriguez, Y., Depestre, T., \& Gomez, O. (2008). Efficiency of selection in pepper lines (Capsicum annuum) from four subpopulations in characters of productive interest. Cienciae Investigación Agraria, 35(1), 29-40

Sahi, I. Y., \& Khalid, A. N. (2007): In vitro biological control of Fusarium oxysporum causing wilt in Capsicum annuum. Mycopath., 5(2), 85-88.

Sally, A. M., Randal, C. R., \& Richard, M. R. (2006). Fusarium Verticillium wilts of Tomato, Potato, Pepper and Eggplant. The Ohio State University, USA.

Sanogo, S., (2003). Chile pepper and the threat of wilt diseases. Online Plant Health Progress. https://doi.org/ 10.1094/PHP-2003-0430-01-RV

Sekhon, R. K., \& Singh, P. (2007). Influence of edaphic factors and cultural practices on the development of Fusarium wilt of muskmelon. Research Punjab Agricultural University, 44(1), 50-54.

Sela-Buurlage, M. B, Budai-Hadrian, O., Pan, Q., Carme-Goren, L., Vunsch, R., Zamir, D., \& Fluhr, R. (2001). Genome-wide dissection of Fusarium resistance in Tomato reveals multiple complex loci. Molecular Genetics Genomics, 265, 1104-1111. https://doi.org/10.1007/s004380100509

Serrano-Alonso, Y., Aguilar-Perez, M. I., Gómez-Uroz, R., \& Gomez-Vazquez, J. (2014). Damping off and root rot of pepper caused by Fusarium oxysporum in Almería Province, Spain. Plant Disease, 98(8), 1159-1160. https://doi.org/10.1094/PDIS-02-14-0212-PDN

Shafique, S., Asif, M., \& Shafique, S. (2015). Management of Fusarium oxysporum f.sp. capsici by leaf extract of Eucalyptus citriodora. Pakistan Journal of Botany, 47(3), 1177-1182.

Sharma, K. D., \& Muehlbauer, F. J. (2007). Fusarium wilt of chickpea: physiological specialization, genetics of resistance and resistance gene tagging. Euphytica, 157, 1-14. https://doi.org/10.1007/s10681-007-9401-y

Sheu, Z. M., \& Wang, T. C. (2006). First Report of Race 2 of Fusarium oxysporum f. sp. lycopersici, the causal agent of Fusarium wilt on Tomato in Taiwan. The American Phytopathological Society, 90(111). https://doi.org/10.1094/PD-90-0111C

Shiferaw, M., \& Alemayehu, C. (2014). Assessment of Hot Pepper (Capsicum species) Diseases in Southern Ethiopia. International Journal of Science and Research, 3, 2319-7064.

Shimeles, A., Berhanu, B., \& Bekele, K. (2007). Survey report on current pepper production constraints in major pepper growing areas of Ethiopia. EIAR, Addis Abeba, Ethiopia

Singh, P. K., \& Kumar, V. (2011). Fusarium wilt of chrysanthemum—Problems and prospects. Plant Pathology and Quarantine, 4(1), 34-44. https://doi.org/10.5943/ppq/4/1/5

Singh, U. S., \& Zaidi, N. W. (2002). Current Status of formulation and delivery of fungal and bacterial antagonists for disease management in India. In R. J. Rabindra, S. S. Hussaini, \& B. Ramanujam (Eds.), Microbial Biopesticide Formulations and Application (pp. 168-179). Project Directorate of Biological Control, Bangalore.

Sitara, U., \& Hasan, N. (2011). Studies on the efficacy of chemical and non chemical treatments to control mycoflora associated with chilli seed. Pak. J. Bot., 43, 95-110.

Smith, I. M., Dunez, J., Phillips, D. H., Lelliott, R. A., \& Archer, S. A. (1988). European handbook of plant diseases (p. 583). Blackwell Scientific Publications, Oxford. https://doi.org/10.1002/9781444314199

Stakheev, A. A., Ryazantsev, D. Y., \& Zavriev, S. K. (2011). Novel DNA markers for taxonomic characterization and identification of Fusarium species. Russian Journal of Bio-organic Chemistry, 37(5), 593-601. https://doi.org/10.1134/S1068162011050189

Stephen, A. F., \& Andre, K. G. (2003). Fusarium oxysporum. Department of Plant Pathology, CTAHR University of Hawaii at Manoa. 
Stover, R. H. (1970). Banana root diseases caused by Fusarium oxysporum f.sp. cubense, Pseudomonas solanacearum and Radopholus similis: A comparative study of life cycles in relation to control. In T. A. Toussoun, R. V. Bega, \& P. E. Nelson (Eds.), Root diseases and soil-borne pathogens (pp. 197-200), Berkeley: University California Press.

Tameru, A. (2004). Characterization of virus of pepper (Capsicum spp.) and sweet potato (Ipomoea batatas) from Ethiopia (p. 150, PhD Thesis, University of Bonn, Germany).

Tameru, A., Hamacher, J., \& Dehne, H. W. (2003). The increase in importance of Ethiopian Pepper Mottle Virus $(E P M V)$ in the rift valley part of Ethiopia: Time to create Awareness among researchers an extension workers. Paper presented at Deutsches Tropentage, October 18-21, 2003, Gottingen, Germany.

Teshome, B. S., Chemeda, F., \& Dereje, G. (2012). Integrated Approach and Plant Extract Management Options against Pepper Wilt (Fusarium oxysporum Var. Vasinfectum) at Bako, Western Ethiopia.

Thangavelu, R., Palaniswani, A., \& Velazhahan, R. (2003). Mass production of Trichoderma harzianum for managing Fusarium wilt of banana. Agricultural Ecosystem and Environment, 103, 259-263. https://doi.org/ 10.1016/j.agee.2003.09.026

Thijs, R. (2010). Analysis of supply side constraints on Ethiopian red pepper and paprika capsicum production and export (Master thesis, Utrecht University, Branson).

Tu, J. C. (1994). Effects of soil compaction, temperature, and moisture on the development of the Fusarium root rot complex of pea in south western Ontario. Phytoprotection, 75(3), 125-131. https://doi.org/10.7202/ 706059ar

Walter, S., Nicholson, P., \& Dooha, F. M. (2009). Action and reaction of host and pathogen during Fusarium head blight disease. New Phytologist, 185, 54-66. https://doi.org/10.1111/j.1469-8137.2009.03041.x

Wongpia, A., \& Lomthaisong, K. (2010). Changes in the 2DE protein profiles of chilli pepper (Capsicum annuum) leaves in response to Fusarium oxysporum infection. Science Asia, 36, 259-270. https://doi.org/10.2306/scienceasia1513-1874.2010.36.259

Zaher, E. A., Abada, K. A., \& Zyton, M. A. (2013). Effect of combination between bioagents and solarization on management of crown-and stem-rot of Egyptian clover. Journal of Plant Science, 1(3), 43-50.

\section{Copyrights}

Copyright for this article is retained by the author(s), with first publication rights granted to the journal.

This is an open-access article distributed under the terms and conditions of the Creative Commons Attribution license (http://creativecommons.org/licenses/by/4.0/). 